\title{
Significant role of macrophages in human cancers associated with Epstein-Barr virus (Review)
}

\author{
MISUZU SHIMAKAGE \\ Department of Pediatrics, National Hospital Organization, Wakayama National Hospital, Wakayama 644-0044, Japan
}

Received June 20, 2014; Accepted August 21, 2014

DOI: $10.3892 /$ or.2014.3475

\begin{abstract}
Epstein-Barr virus (EBV) is a ubiquitous pathogen that was first identified as a human cancer virus. Many human cancers are associated with EBV, and we demonstrated that EBV infects macrophages. Macrophages infected with EBV show a close correlation with many human cancers, and thus more attention must be given to the role of macrophages infiltrating into cancer tissues associated with EBV. In this review, I discuss the role of macrophages in the process of EBV-associated oncogenesis with regard to interleukin-10.
\end{abstract}

\section{Contents}

1. Introduction

2. BamHIW

3. EBV leader protein

4. EBV nuclear antigen-2

5. Latent membrane protein-1

6. EBV-encoded non-polyadenylated RNA-1

7. EBV transcripts and human diseases

8. Lytic infection of EBV in neoplastic tissues

9. Radiation therapy and EBV-positive neoplasms

Correspondence to: Dr Misuzu Shimakage, Department of Pediatrics, National Hospital Organization, Wakayama National Hospital, 1138 Wada, Mihama-cho, Hidaka-gun, Wakayama 644-0044, Japan

E-mail: shimakage@rose.plala.or.jp; misuzu_s@wakayama2.hosp.go.jp

Abbreviations: ALCL, anaplastic large-cell lymphoma; BCRF1, BamHIC coding rightward reading frame-1; BZLF1, BamHIZ coding leftward reading frame-1; CIN, cervical intraepithelial neoplasia; CTCL, cutaneous T-cell lymphoma; EBER1, EBV-encoded non-polyadenylated RNA-1; EBNA LP, EBV nuclear antigen leader protein; EBNA2, EBV nuclear antigen-2; EBV, EpsteinBarr virus; IL-10, interleukin-10; ISH, in situ hybridization; LCH, Langerhans cell histiocytosis; LMP1, latent membrane protein-1; NPC, nasopharyngeal carcinoma; RCC, renal cell carcinoma; SCC, squamous cell carcinoma; TAM, tumor-associated macrophage

Key words: Epstein-Barr virus, human cancer, macrophages, tumor-associated macrophages, in situ hybridization
10. Infection and replication of EBV in macrophages

11. Tumor-associated macrophages

12. Discussion

\section{Introduction}

Of the 12.7 million new cancer cases that occurred in 2008 in the world, the population-attributable fraction for infectious agents was $16.1 \%$, and that of Epstein-Barr virus (EBV) was $5.4 \%$ (1). EBV is a ubiquitous virus that infects almost all adults throughout the world. EBV is also known as a causative agent of i) Burkitt's lymphoma, an endemic malignant tumor in East African children; ii) nasopharyngeal carcinoma (NPC), which has a tendency of high occurrence in the Chinese and iii) various tumors associated with immuno-suppressive states such as those observed post-transplantation and in $\operatorname{AIDS}(2,3)$. Although foods, environment, and genetic differences must be considered, I hypothesized that more human tumors are generated by EBV infection than has been reported, and to test this hypothesis EBV transcripts were examined in various human tumors with mRNA in situ hybridization (mRNA ISH) and immunofluorescence staining. The results of these procedures showed that EBV infects and proliferates in macrophages. The neoplasms of macrophage-related cells were also investigated. Seven types of cancer other than NPC, four types of lymphoma, and Langerhans cell histiocytosis (LCH) expressed EBV transcripts, including its oncogenes. None of the patients examined herein showed an immunocompromised state, and most of the patients with LCH were North American. Here, I review the recent reports correlating EBV transcripts with human cancers, and I discuss the role of macrophages in the oncogenesis of EBV.

\section{BamHIW}

BamHIW is a leader sequence of some EBV transcripts. EBV contains multiple copies of a 3-kb BamHIW repeat sequence. A better detection effect can thus be expected with the use of this sequence as the probe for mRNA ISH. I treated to remove 830 bases containing the 'Alu-family'-like sequence from the BamHIW fragment, and used the resulting 2.27-kb sequence for the mRNA ISH (4). BamHIW transcripts were detected in almost all of the neoplasms examined (Table I).

Although breast cancers were not examined, a 1995 study that used polymerase chain reaction (PCR) over a region of 
BamHIW found that $21 \%$ of the breast cancer specimens evaluated were positive for EBV DNA (5). Tierney et al reported that the five-repeat number of BamHIW was most effective for B-cell transformation (6).

\section{EBV leader protein}

Allan et al reported that EBV leader protein (EBNA-LP) transfectants grew faster than control cells (7). Peng et al showed that EBNA LP is a gene-specific coactivator of EBNA2 (8). We showed EBNA-LP expression in various human cancers (9). Portal et al reported that EBNA-LP dismisses the transcription repressors NCoR and RBPJ from promoters and enhancers, and that EBNA-LP and transcription factors act in the repressor deletion and gene activation necessary for lymphoblastoid cell line growth and survival (10).

\section{EBV nuclear antigen-2}

Tumorigenicity of EBV nuclear antigen-2. In a previous study, I demonstrated that EBV nuclear antigen-2 (EBNA2) is a strong oncogene of EBV (11). After a 2-3-week inoculation of a transfected rat fibroblast cell line with a recombinant EBNA2 expression plasmid, four of seven clones reproducibly formed tumors in nude mice. All of these tumorigenic clones could be grown in low serum, and two of the four tumorigenic clones formed colonies in soft agar. These four tumorigenic clones showed EBNA2 expression, but the non-tumorigenic clones did not. These results indicate that the expression of EBNA2 is correlated with tumorigenicity.

Detection of EBNA2 expression. The mRNA expression of EBNA2 can be detected with the mRNA ISH protocol that we established (12), and the EBNA2 protein expression can be detected with indirect immunofluorescence staining using a monoclonal antibody.

Other functions of EBNA2. In 2009, Pan et al indicated that EBNA2 disrupts the mitotic checkpoint and causes chromosomal instability; this was a newly discovered function of EBNA2 in cell-cycle regulation (13). More recently, Sano et al reported that EBNA2-deleted EBV can infect rabbits with lower efficiency than prototype EBV (14). This finding suggests that oncogenicity and infectivity may be correlated, although these two functions have been described as independent in the case of EBV-encoded nonpolyadenylated RNAs (EBERs) (15).

Rosato et al found that EBNA2 regulates microRNA (miR)-21 and miR-146a (16). EBV contains microRNAs near the downstream of EBNA2 and exploits RNA silencing as a convenient method for gene regulation in a nonimmunogenic manner (17).

\section{Latent membrane protein-1}

The transformation of mouse cells by the latent membrane protein-1 (LMP1) gene of EBV was reported by Baichwal et al (18). LMP1 was reported to have a role in the carcinogenesis of NPC (19). Kim et al also showed that the transformation of canine kidney epithelial cells by LMP1 formed spheroidal cysts in collagen gel matrix and induced invasive growth (20). Shair et al compared the development of papilloma and carcinoma in epithelial cells of transgenic mice with model carcinogens DMBA and TPA, and they found that LMP1 was a weak promoter, that it increased papilloma formation, and that it slightly increased squamous cell carcinoma (SCC); the development of SCC was significantly increased in LMP2A double-transgenic animals (21).

\section{EBV-encoded non-polyadenylated RNA-1}

Although Swaminathan et al reported in 1991 that EBER-deleted recombinant EBV transformed lymphocytes (22), many reports describing EBER oncogenesis have accumulated since that date $(23,24)$. Most EBV-encoded non-polyadenylated RNA-1 (EBER1) detection has been accomplished with commercial RNA ISH kits, whereas I examined EBER RNA ISH with probes I prepared myself. Although many copies of EBER1 exist, there is a report that false-negative results are most often observed (25). Almost all of the English language studies regarding EBV-associated neoplasms and EBV expression used EBER1 RNA ISH alone. However, this method needs to be further investigated. Through my experiences with mRNA ISH results, I observed that relatively higher sensitivity was achieved with BamHIW mRNA ISH compared to EBER1 RNA ISH (Table I).

\section{EBV transcripts and human diseases}

I examined many human tumors: mesopharyngeal and hypopharyngeal carcinoma (26) as well as NPC (27), oral cancer $(9,28)$, thyroid carcinoma $(9,29)$, renal cell carcinoma (RCC) (30), testicular tumors $(4,9)$, uterine cervical carcinoma $(12,31)$, anaplastic large-cell lymphoma $(32,33)$, cutaneous T-cell lymphoma $(9,34)$, leptomeningeal lymphoma (35), lymphoproliferative diseases in the lung (36) and LCH (37) by means of BamHIW, EBNA LP, EBNA2 mRNA ISH and EBER1 RNA ISH, and by immunofluorescence staining using monoclonal EBNA LP, EBNA2, LMP1, and BZLF1 (BamHIZ coding leftward reading frame-1) antibody. The recent reports concerning these diseases, in which I examined EBV transcripts, are discussed below.

Mesopharyngeal and hypopharyngeal carcinoma. No new reports are available.

Oral cancer. Using an LMP1-specific antibody, Shamaa et al found that EBV and DNA topoisomerase II correlate with oral epithelial dysplasia and oral SCC (38). Slots et al reported that they detected EBV DNA in $60-80 \%$ of aggressive periodontitis lesions and in 15-20\% of gingivitis lesions or normal periodontal sites (39). Jalouli et al reported that of 155 oral SCC samples examined, 85 were positive for EBV by nested PCR (40). Szkaradkiewicz et al found that 12 of 14 cases of tonsillar carcinoma and 12 of 14 cases of tongue carcinomas showed EBV DNA positivity with PCR, and they reported that EBV was associated with these carcinomas much more frequently compared to human papilloma virus (41). DNA was detected in $19.2 \%$ of oral SCCs and the expression of LMP-1 was found in $85.7 \%$ of EBV-positive oral SCCs (42). In 
another examination, EBV DNA was detected in $15.2 \%$ of oral SCCs (43). Frangou et al reported the rare detection of EBV replication in tongue epithelial cells $(44,45)$. Walling et al described that approximately 1 in $10^{5}$ pre-Langerhans cells harbor latent EBV infection in vivo, a frequency similar to B lymphocytes in healthy individuals, and they proposed a new model of EBV transition from blood to oral epithelium; they speculated that the infected Langerhans cells serve as a reservoir of EBV in oral epithelial cells (46).

Thyroid carcinoma. A rare case of thyroid involvement by malignant histiocytosis of the Langerhans cell type was reported in 1996 (47), but its association with EBV is unclear. There are many reports regarding LCH co-existing with papillary thyroid cancer, but none of the relevant studies examined EBV. Furthermore, some reports described that numerous tumor-associated macrophages (TAMs) were distributed in advanced thyroid cancer and thyroid papillary carcinoma, and that an increased density of macrophages is associated with decreased survival, but none of these reports mentioned an association with EBV $(48,49)$.

Renal cell carcinoma. EBV infection was reported in sarcomatoid renal cell carcinoma (RCC) tissues (50). In my experience, one case of sarcomatoid RCC expressed EBV transcripts (30). There is a report that gastric cancer and concomitant RCC were both positive for EBV (51).

Testicular carcinoma. Although there are some negative reports concerning testicular cancer and EBV $(52,53), \mathrm{EBV}$ in relation to testicular cancer risk (54) and EBV infection and the risk of testicular cancer in offspring (55) have been described.

Uterine cervical carcinoma. There are many reports of EBV association with uterine cervical carcinoma, but almost all used data obtained by PCR; the detection of EBV transcripts is very rare. Using nested PCR, Santos et al examined 66 women with high-grade cervical intraepithelial neoplasia (CIN) and 14 women with invasive cervical cancer, and they found that the invasive cancer group showed significantly higher positivity for EBV (56). Kim et al showed similar results of EBV positivity, and they noted that p16 methylation was observed in the cases of EBV-positivity (57). Szostek et al found EBV integration in $50 \%$ of cervical SCCs, but not in CIN (58).

Anaplastic large-cell lymphoma. Since the WHO classification system was changed in 2004, cases of anaplastic large-cell lymphoma (ALCL) may not be the same as those before 2004. Here, I describe the ALCL according to the criteria of the classification at each period of time.

Kuse et al reported that EBV was detected with EBER1 ISH in 6 of 17 cases of CD30 ALCL, and all EBER1-positive cases showed LMP1 expression and 2 of those 6 cases showed EBNA2 expression with immunohistochemistry (59). Tazzari et al described an EBV-infected cell line which grows in SCID mice with the morphologic features of $\mathrm{CD} 30^{+}$ ALCL (60). EBV association in ALCL was also reported by Agarwal et al (61). A report from Pakistan showed that EBV DNA was amplified in 28 of 37 cases of ALCL (62). Another report from Korea noted that two of $16 \mathrm{CD} 30^{+}$ALCL cases showed EBER positivity by ISH (63). A study conducted in India showed that EBV DNA was amplified by EBNA1 and EBNA3C PCR in 4 of 6 ALCL cases (64). Ma et al presented a case report and discussion of 63 reported cases of $\mathrm{EBV}^{+}$ ALCL (65). Although the WHO Classification of Tumors of Haematopoietic and Lymphoid Tissue 2008 edition states that ALCL is consistently negative for EBV, and many negative results were reported (66-69), reports of EBV-positive ALCL cases have been reported after $2008(64,65)$.

Cutaneous T-cell lymphoma. Park and Ko reported that 5 of 12 cutaneous T-cell lymphoma (CTCL) cases showed EBER positivity by ISH (70), and Erkek et al showed that 9 of 92 subjects with mycosis fungoides (MF) evidenced EBV DNA (71). In a study by Novelli et al, 7 of $71 \mathrm{MF}$ cases were EBV DNA-positive by PCR, but EBER signals were negative by ISH (72). Copur et al reported the full clinical recovery of a patient with EBV-associated CTCL after topical acyclovir treatment (73).

Langerhans cell histiocytosis. Although EBV DNA was detected in 3 of $19 \mathrm{LCH}$ patients by PCR, no signal of EBERs in LCH cells was revealed by ISH, and thus the experiments did not support the role of EBV in the pathogenesis of 83 patients with LCH (74). However, there are some reports supporting EBV pathogenesis of $\mathrm{LCH}$. Csire et al found that antiviral therapy effectively cleared EBV (75), which I also reported in 2004 with one patient (37). The development of LCH was also described with chronic active EBV infection (76). As shown in Table I, immunofluorescence of BZLF1 was detected in all $\mathrm{LCH}$ cases, which showed lytic infection occurring in $\mathrm{LCH}$, and thus LCH was sensitive to acyclovir $(37,75)$.

\section{Lytic infection of EBV in neoplastic tissues}

I frequently observed the lytic infection of EBV in human neoplastic tissues, and my review of the literature revealed the following. An EBV-positive epithelial cell tumor, gastric carcinoma, and NPC showed ganciclovir susceptibility, which indicated lytic infection of the tumors (77). Sporadic lytic viral replication was observed in breast carcinoma cell lines (78). In NPC cells, EBV lytic infection was reported to induce interleukin-10 (IL-10) in monocytes (79). The data regarding IL-10, monocytes and macrophages will be examined further in the 'Discussion' section. Viral reactivation from latency was controlled by the expression of BZLF1 of EBV, and Murata and Tsurumi recently found that histone $\mathrm{H} 3$ lysin 27 trimethylation and H4K20me3 markers are crucial for the suppression of BZLF1 (80). These results are expected to be useful in the development of therapy for EBV-positive cancers using epigenetic disruptors.

\section{Radiation therapy for EBV-positive neoplasms}

Our group reported increased sensitivity of EBNA2transformed cells to ionizing radiation (81), and more recent studies have followed up on this finding. Plasma EBV DNA levels significantly decreased after radiotherapy (82). Among 270 patients with CTCL, complete response was observed in 255 patients treated with $700-800$ cGy (83). 


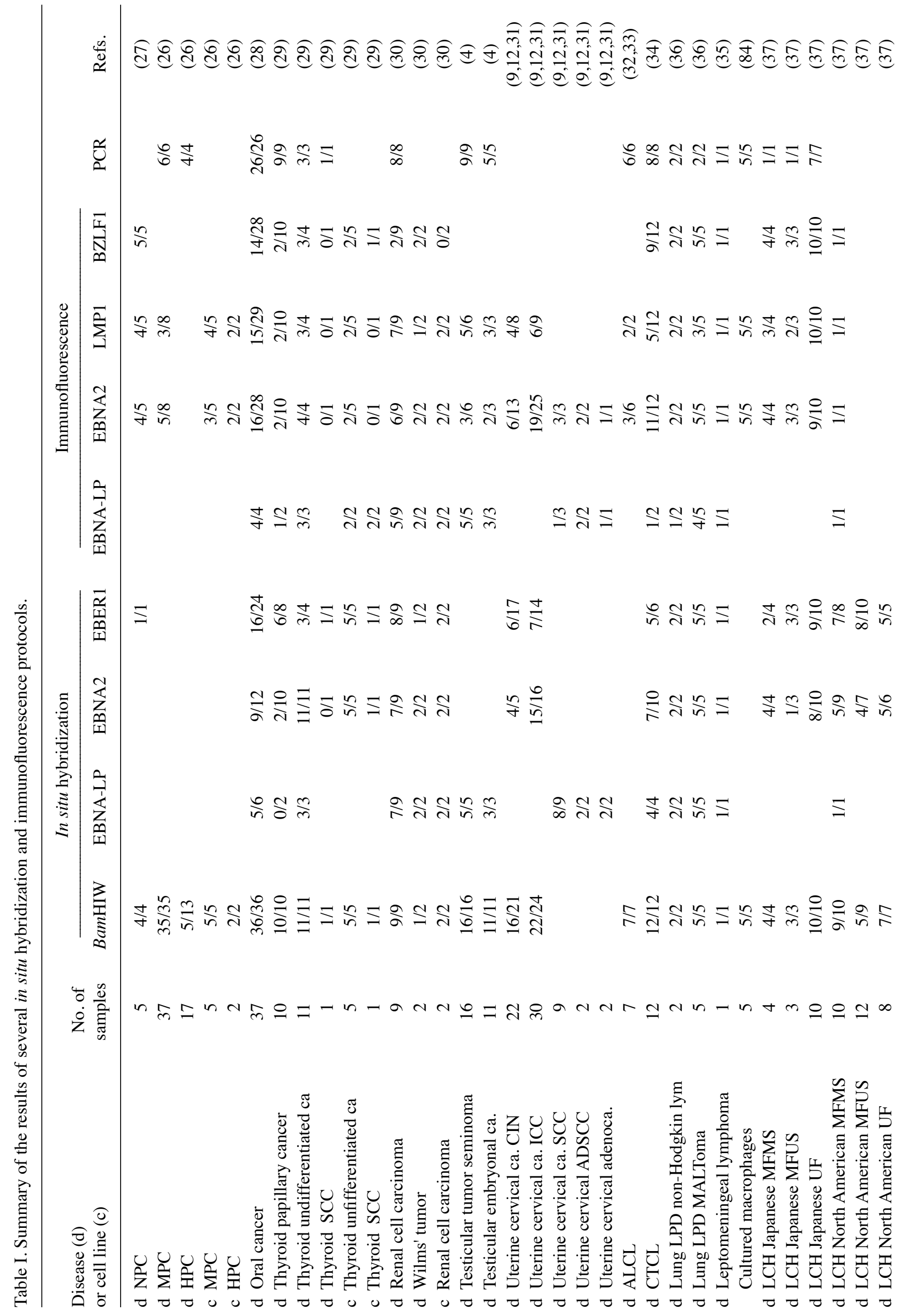




\section{Infection and replication of EBV in macrophages}

We demonstrated EBV infection and replication in macrophages in 1999 (84). In 2002, Masy et al showed that human monocytic cell lines transformed by EBV displayed EBNA-1 and LMP-1 but not EBNA-2, and these cells were tumorigenic after injection in nude mice (85). In 2004, Salek-Ardakani et al reported that EBV promoted human monocyte survival and maturation, and they mentioned that these cells may serve as a vehicle for the dissemination of the virus (86). Using experiments with tongue and buccal explants with EBV, Tugizov et al found that EBV first infected submucosal monocytes, then migrated into the epithelium and spread to oral epithelial cells. They also described EBV-positive macrophages in oral hairy leukoplakia tissues (87).

Using murine gammaherpesvirus 68 , which is genetically related to EBV, Li et al showed that a replication-defective gammaherpesvirus 68 mutant virus established a long-term infection in macrophages, and the number of B cells harboring the viral genome was greatly reduced in the absence of lytic infection (88). On the other hand, an enhanced outgrowth of EBV-transformed chronic lymphocytic leukemia B cells was described to be mediated by coculturing with macrophage feeder cells (89).

\section{Tumor-associated macrophages}

Although the association with EBV was not examined, $85 \%$ of human macrophages expressed the Hodgkin's cell-associated antigen Ki-1 (CD30) in vitro, whereas normal human monocytes did not express the antigen (90). This finding indicates that the progression from monocyte to macrophage needs the expression of CD30 in at least $85 \%$ of the cases. EBV is suspected to participate in this progression with the production of IL- 10 . These findings will be evaluated in the 'Discussion' section.

The inflammatory process has been indicated to be a cofactor in carcinogenesis, where tumor-associated macrophages (TAMs) have been found to be a major component of the infiltrate of tumors (91). TAMs have also been described to enhance tumor progression and metastasis (92). Interactions between macrophages and lymphocytes in cancer have been discussed $(93,94)$. Regarding RCC, 98 RCC patients were examined and correlations were identified for TAMs, microvessel density and the proliferative index with a tendency for poor prognosis (95) and the coculture of macrophages with RCC cells induced TAMs and the activation of signal transducers or activators (96). Macrophage recruitment was also suggested to be associated with the disease progression of Wilms' tumor (97).

We detected TAMs in many EBV-associated neoplasms including RCC, uterine carcinoma, oral cancer and others; TAMs, which were in situ hybridized with EBV antisense RNAs, were double-stained immunohistochemically with monoclonal anti-CD68 antibody (98). These findings indicate that TAMs infiltrate into EBV-associated neoplasms that express EBV transcripts, and they suggest a strong influence on oncogenesis.

\section{Discussion}

A summary of our experiments is shown in Table I. The sensitivity of the detection of EBV expression was higher with 


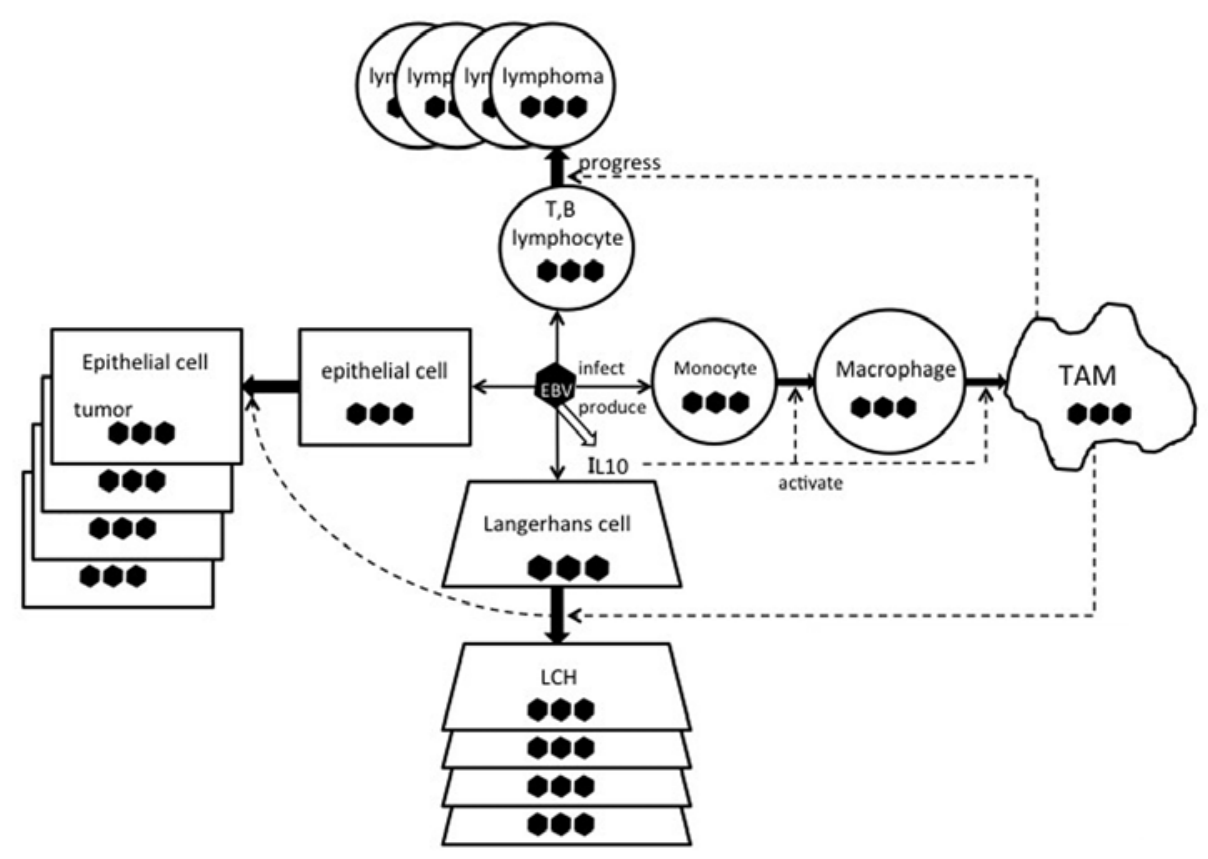

Figure 1. Expected pathways of oncogenesis of lymphocytes, Langerhans cells and epithelial cells with Epstein-Barr virus (EBV) as well as the expected pathways of activation of tumor-associated macrophages (TAMs) in the process of EBV oncogenesis. EBV infects and proliferates in T-lymphocytes, B-lymphocytes, Langerhans cells, epithelial cells and macrophages. In lymphocytes, Langerhans cells and epithelial cells, EBV-infected cells are transformed and grow tumors. In macrophages, IL-10, which is produced by EBV, activates monocytes and macrophages to grow TAMs resulting in the progression of EBV-associated tumors. Symbols in the figure: hexagon, Epstein-Barr virus; arrow, infection; white arrow, production; thick black arrow, progression; dotted arrow, activation.

the ISH method compared to immunofluorescence; BamHIW mRNA ISH was the highest and the next was EBNA-LP mRNA ISH. Almost all human cancers examined showed EBV expression: not only EBNA2 but also EBNA LP, EBER1, LMP1 and BamHIW. PCR was positive for all samples examined. These results indicate that many human neoplasms other than NPC and Burkitt's lymphoma correlate with EBV. The expression rate was almost uniform irrespective of the disease. This may be due to the limits of detection sensitivity and/or to the finding that all of the human organs examined were infected with EBV uniformly at the time of tumor development. Lung adenocarcinomas and SCCs (containing no case of lymphoepithelioma-like carcinoma) did not express EBV (data not shown); therefore, the hypothesis that EBV is associated with all human neoplasms is denied. In addition, the cell lines showed a higher incidence of positivity compared to the tissue sections, except for BZLF1 immunofluorescence.

Although the association between EBV and human neoplasms has been accepted in a restricted number of diseases, I propose that more attention should be paid to EBV-associated human cancers. The reasons are as follows. As indicated above, much epidemiological data have now been accumulated; in tissue cultures, EBV is one of the most potent transforming viruses (11); EBV persists in circulating memory cells and therefore will be found in all tissues (99); and in CTCL and LCH, some cases showed full clinical recovery after acyclovir treatment $(37,73,75)$.

Moreover, BamHIC coding rightward reading frame-1 (EBV BCRF1) protein shows $84 \%$ sequence homology to human IL-10 (100). IL-10 is a known growth and activation factor for B cells (101). EBV IL-10 could act on multiple cell types and inhibit cytokine synthesis by both T cells and NK cells (102). EBV-derived IL-10 is thought to play a role in the establishment of latent infection by suppression of the host immune system (103).

The macrophage involvement of EBV, which is described above, is also an important problem. IL-10 and viral IL-10 (v-IL-10) strongly reduce antigen-specific human T-cell proliferation by diminishing the antigen-presenting capacity of monocytes (104), and IL-10 promotes the differentiation of monocytes to mature macrophages and blocks their differentiation to dendritic cells (105). The transfection of v-IL-10 into murine cells resulted in tumors after 4 weeks and showed local immunosuppressive effects which depended on the v-IL-10 dose (106). The conservation and mutation of the v-IL-10 gene in various EBV isolates (107) and in human gastric carcinomas and NPCs were also reported (108). Although EBV association was not examined, Lee et al showed that bone morphogenic proteins (BMPs) in RCC promoted tumor proliferation through an IL-10-dependent M2 polarization of TAMs with mouse cell lines and 50 samples of human RCC, and they showed that BMP-6/IL-10/CD68 was associated with a poor prognosis (109). The interactions between EBV, IL-10, and TAMs are illustrated in Fig. 1.

Epidemiological information takes priority over the investigation of mechanisms, and the epidemiological evidence must be therefore accumulated. Virus-directed therapeutics against EBV-associated malignancies have been reported, which include EBV lytic phase induction followed by anti-herpesvirus drug mainly for EBV-positive lymphoid tumors (110), and for EBV-positive epithelial cell tumors (111), followed by radiation therapy for EBV-positive epithelial cell 
tumors (112). Radiation therapy should be recommended for EBV-associated neoplasms, since EBNA2 is sensitive to ionizing radiation (81). It is suspected that infected Langerhans cells serve as a reservoir of EBV in oral epithelial cells (46), and following this infection, oral epithelial dysplasia and SCC are induced (28). The role of macrophages in the oncogenesis of EBV merits further study. The effect of acyclovir and radiation for treatment of EBV-associated neoplasms must be further studied.

\section{References}

1. de Martel, Ferlay J, Franceschi S, Vignat J, Bray F, Forman D and Plummer M: Global burden of cancers attributable to infections in 2008: a review and synthetic analysis. Lancet Oncol 13: 607-645, 2012

2. Young LS and Murray PG: Epstein-Barr virus and oncogenesis: from latent genes to tumours. Oncogene 22: 5108-5121, 2003.

3 . Young LS and Rickinson AB: Epstein-Barr virus: 40 years on. Nat Rev Cancer 4: 757-768, 2004.

4. Shimakage M, Oka T, Shinka T, Kurata A, Sasagawa T and Yutsudo M: Involvement of Epstein-Barr virus expression in testicular tumors. J Urol 156: 253-257, 1996.

5. Labrecque LG, Barnes DM, Fentiman IS and Griffin BE: Epstein-Barr virus in epithelial cell tumors: A breast cancer study. Cancer Res 55: 39-45, 1995.

6. Tierney R, Kao K-U, Nagra JK and Rickinson AB: Epstein-Barr virus BamHIW repeat number limits EBNA2/EBNA-LP coexpression in newly infected B cells and the efficiency of B-cell transformation: a rationale for multiple $\mathrm{W}$ repeats in wild-type virus strains. J Virol 85: 12363-12375, 2011.

7. Allan GJ, Inman GJ, Parker BD, Rowe DT and Farrell PJ: Cell growth effects of Epstein-Barr virus leader protein. J Gen Virol 73: 1547-1551, 1992.

8. Peng RS, Moses SC, Tan J, Kremmer E and Ling PD: The Epstein-Barr virus EBNA-LP protein preferentially coactivates EBNA2-mediated stimulation of latent membrane proteins expressed from the viral divergent promoter. J Virol 79 4492-4505, 2005

9. Shimakage M, Harada S, Kawahara K, Oka T, Yanoma S, Horii K and Sasagawa T:. Detection of Epstein-Barr virus nuclear antigen leader protein expression in various human cancers. In: New Developments in Epstein-Barr Virus Research. Umar S. (ed.). Nova Science, New York, pp261-276, 2006.

10. Portal D, Zhou H, Zhao B, Kharchenko PV, Lowry E, Wong L, Quackenbush J, Holloway D, Jiang S, Lu Y and Kieff E: Epstein-Barr virus nuclear antigen leader protein localizes to promoters and enhancers with cell transcription factors and EBNA2. Proc Natl Acad Sci USA 110: 18537-18542, 2013.

11. Shimakage $M$, Kurata $A$, Inoue $H$, Okamoto $Y$ and Yutsudo $M$ : Tumorigenicity of EBNA2-transfected cells. FEBS Lett 371: 245-248, 1995

12. Sasagawa T, Shimakage M, Nakamura M, Sakaike J, Ishikawa $H$ and Inoue M: Epstein-Barr virus (EBV) genes expression in cervical intra-epithelial neoplasia and invasive cervical cancer: A comparative study with human papillomavirus (HPV) infection. Hum Pathol 31: 318-326, 2000.

13. Pan SH, Tai CC, Lin CS, Hsu WB, Chou SF, Lai CC, Chen JY, Tien HF, Lee FY and Wang WB: Epstein-Barr virus nuclear antigen 2 disrupts mitotic checkpoint and causes chromosomal instability. Carcinogenesis 30: 366-375, 2009.

14. Sano H, Nagata K, Kato K, Kanai K, Yamamoto K, Okuno K, Kuwamoto S, Higashi-Mori H, Sugihara H, Kato M, Murakami I, Kanzaki S and Hayashi K: EBNA-2-deleted Epstein-Barr virus from P3HR1 can infect rabbits with lower efficiency than prototype Epstein-Barr virus from B95-8. Intervirology 56 : 114-121, 2013.

15. Wu Y, Maruo S, Yajima M, Kanda T and Takada K: Epstein-Barr virus (EBV)-encoded RNA2 (EBER2) but not EBER1 plays a critical role in EBV-induced B-cell growth transformation. J Virol 81: 11236-11245, 2007

16. Rosato P, Anastasiadou E, Garg N, Lenze D, Boccellato F, Vincenti S, Severa M, Coccia EM, Bigi R, Cirone M, Ferretti E, Campese AF, et al: Differential regulation of miR-21 and miR-146a by Epstein-Barr virus-encoded EBNA2. Leukemia 26: 2343-2352, 2012.
17. Pfeffer S, Zavolan M, Grasser A, Chien M, Russo J, Ju J, John B, Enright AJ, Marks D, Sander C and Tuschi T: Identification of virus-encoded microRNAs. Science 304: 734-736, 2004.

18. Baichwal VR and Sugden B: Transformation of Balb 3T3 cells by the BNLF-1 gene of Epstein-Barr virus. Oncogene 5: 461-467, 1988

19. Zheng H, Li L, Hu D, Deng X and Cao Y: Role of Epstein-Barr virus encoded latent membrane protein 1 in the carcinogenesis of nasopharyngeal carcinoma. Cell Mol Immunol 4: 185-196, 2007.

20. Kim K-R, Yoshizaki T, Miyamori H, Hasegawa K, Horikawa T, Furukawa M, Harada S, Seiki M and Sato H: Transformation of Madin-Darby canine kidney (MDCK) epithelial cells by Epstein-Barr virus LMP1 induces expression of Ets 1 and invasive growth. Oncogene 19: 1764-1771,2000.

21. Shair KH, Bendt KM, Edwards RH, Nielsen JN, Moore DT and Raab-Traub N: Epstein-Barr virus-encoded latent membrane protein 1 (LMP1) and LMP2A function cooperatively to promote carcinoma development in a mouse carcinogenesis model. J Virol 86: 5352-5365, 2012.

22. Swaminathan S, Tomkinson B and Kieff E: Recombinant Epstein-Barr virus with small RNA (EBER) genes deleted transforms lymphocytes and replicates in vitro. Proc Natl Acad Sci USA 88: 1546-1550, 1991.

23. Komano J, Maruo S, Kurozumi K, Oda T and Takada K: Oncogenic role of Epstein-Barr virus-encoded RNAs in Burkitt's lymphoma cell line Akata. J Virol 73: 9827-9831, 1999.

24. Houmani JL, Davis CI and Ruf IK: Growth-promoting properties of Epstein-Barr virus EBER-1 RNA correlates with ribosomal protein L22 binding. J Virol 83: 9844-9853, 2009.

25. Weiss LM and Chen YY: EBER in situ hybridization for Epstein-Barr virus. Meth Mol Biol 999: 223-230, 2013.

26. Shimakage M, Sasagawa T, Yoshino K, Yutsudo M, Kimura M, Yamamoto N, and Yanoma S: Expression of Epstein-Barr virus in mesopharyngeal and hypopharyngeal carcinoma. Hum Pathol 30: 3071-3076, 1999.

27. Chatani M, Teshima T, Inoue T, Yoshino K, Ikegami N, Hirai K and Shimakage M: Antibody response against the Epstein-Barr virus-coded nuclear antigen 2 (EBNA2) in nasopharyngeal carcinoma. Laryngoscope 101: 626-629, 1991.

28. Shimakage M, Horii K, Tempaku A, Kakudo K, Shirasaka T and Sasagawa T: Association of Epstein-Barr virus with oral cancers. Hum Pathol 33: 608-614, 2002.

29. Shimakage M, Kawahara K, Sasagawa T, Inoue H, Yutsudo M, Yoshida A and Yanoma S: Expression of Epstein-Barr virus in thyroid carcinoma correlates with tumor progression. Hum Pathol 34: 1170-1177, 2003.

30. Shimakage M, Kawahara K, Harada S, Sasagawa T, Shinka T and Oka T: Expression of Epstein-Barr virus in renal cell carcinoma. Oncol Rep 18: 41-46, 2007.

31. Shimakage M and Sasagawa T: Detection of Epstein-Barr virusdetermined nuclear antigen-2 mRNA by in situ hybridization. J Virol Meth 93: 23-32, 2001

32. Shimakage M,Dezawa T, Tamura S, Tabata T, Aoyagi N, Koike M, Inoue $\mathrm{H}$, Yutsudo M, Hakura A and Ikegami N: A Ki-1-positive cell line expressing Epstein-Barr virus antigens, established from child with Ki-1-positive lymphoma. Intervirology 36: 215-224, 1993.

33. Shimakage M, Nakamine H, Tamura S, Takenaka T, Yutsudo M and Hakura A: Detection of Epstein-Barr virus transcripts in anaplastic large-cell lymphoma by mRNA in situ hybridization. Hum Pathol 28: 1415-1419, 1997.

34. Shimakage M, Sasagawa T, Kawahara K, Yutsudo M, Kusuoka H and Kozuka T: Expression of Epstein-Barr virus in cutaneous T-cell lymphoma including mycosis fungoides. Int J Cancer 92: 226-231, 2001 .

35. Nakajima H, Shimakage M, Takeda Y. Furutama D, Sugino M, Kimura F, Shibayama Y and Hanafusa T: Epstein-Barr virusassociated primary leptomeningeal lymphoma. Eur J Neurol 13: e4-e6, 2006.

36. Shimakage M, Sakamaoto H, Harada S, Sasagawa T and Kodama K: Expression of the Epstein-Barr virus in lymphoproliferative diseases of the lung. Oncol Rep 17: 1347-1352, 2007.

37. Shimakage M, Sasagawa T, Kimura M, Shimakage T, Seto S, Kodama K and Sakamaoto H: Expression of Epstein-Barr virus in Langerhans' cell histiocytosis. Hum Pathol 35: 862-868, 2004.

38. Shamaa A, Zyada M, Wagner M, Awad S, Osman MM and Azeem AA: The significance of Epstein-Barr virus (EBV) \& DNA topoisomerase II alpha (DNA-topo II alpha) immunoreactivity in normal oral mucosa, oral epithelial dysplasia (OED) and oral squamous cell carcinoma (OSCC). Diagnostic Pathol 3: $45-57,2008$. 
39. Slots J, Saygun I, Sabeti M and Kubar A: Epstein-Barr virus in oral diseases. J Periodontal Res 41: 235-244, 2006.

40. Jalouli J, Lalouli MM, Sapkota D, Ibrahim SO, Larsson PA and Sand L: Human papilloma virus, herpes simplex virus and Epstein-Barr virus in oral squamous cell carcinoma from eight different countries. Anticancer Res 32: 571-580, 2012.

41. Szkaradbiewicz A, Kruk-Zagajewska A, Wal M, Jopek M, Wierzbicka A and Kuch A: Epstein-Barr virus and human papillomavirus infections and oropharyngeal squamous cell carcinoma. Clin Exp Med 2: 137-141, 2002.

42. Gonzalez-Moles MA, Gutierrez J, Rodriquez MJ, Ruiz-Avila I and Rodriquez-Archilla A: Epstein-Barr virus latent membrane protein-1 (LMP-1) expression in oral squamous cell carcinoma. Laryngoscope 112: 482-487, 2002.

43. Kobayashi I, Shima K, Saito I, Kiyoshima T, Matsuo K, Ozeki S, Onishi M and Sakai H: Prevalence of Epstein-Barr virus in oral squamous cell carcinoma. J Pathol 189: 34-39, 1999.

44. Herrmann K, Frangou P, Middeldorp J and Niedobitek G: Epstein-Barr virus replication in tongue epithelial cells. J Gen Virol 83: 2995-2998, 2002.

45. Frangou P, Buettner M and Niedobitek G: Epstein-Barr virus (EBV) infection in epithelial cells in vivo: rare detection of EBV replication in tongue mucosa but not in salivary glands. J Infect Dis 191: 238-242, 2005

46. Walling DM, Ray AJ, Nichols JE, Flaitz CM and Nichols CM: Epstein-Barr virus infection of Langerhans cell precursors as a mechanism of oral epithelial entry, persistence, and reactivation. J Virol 81: 7249-7268, 2007.

47. Kitahara S, Iitaka M, Shimizu T, Serizawa N, Fukasawa N, Miura S, Kawasaki S, Yamanaka K, Kawakami Y, Murakami S, Ishii $\mathbf{J}$ and Katayama S: Thyroid involvement by malignant histiocytosis of Langerhans' cell type. Clin Endocrinol 45: 357-363, 1996.

48. Ryder M, Ghossein RA, Ricarte-Filho JCM, Knauf JA and Fagin JA: Increased density of tumor associated macrophages is associated with decreased survival in advanced thyroid cancer. Endocr Relat Cancer 15: 1069-1074, 2008.

49. Liotti F, Visciano C and Melillo RM: Inflammation in thyroid oncogenes. Am J Cancer Res 2: 286-297, 2012.

50. Kim KH, Han EM, Lee ES, Park HS, Kim I and Kim YS: Epstein-Barr virus infection in sarcomatoid renal cell carcinoma tissues. BJU Int 96: 547-552, 2005

51. Betge J, Pollheimer MJ, Schelemmer A, Hoefler G and Langner C: Gastric cancer and concomitant renal cancer: A systematic immunohistochemical and molecular analysis. Oncol Rep 26: 567-575, 2011.

52. Rajpert-De Meyts E,Hørding U, Nielsen HW and SkakkebaekNE: Human papillomavirus and Epstein-Barr virus in the etiology of testicular germ cell tumours. APMIS 102: 38-42, 1994.

53. Fend F, Hittmair A, Rogatsch H, Gredler E, Obrist P and Mikuz G: Seminomas positive for Epstein-Barr virus by the polymerase chain reaction: viral RNA transcripts (Epstein-Barr-encoded small RNAs) are present in intratumoral lymphocytes but absent from the neoplastic cells. Mod Pathol 8: 622-625, 1995.

54. Arke O, Lipworth L, Tretli S, Linde A, Engstrand L, Adami HO, Melbye M, Andersen A and Ekbom A: Epstein-Barr virus and cytomegalovirus in relation to testicular-cancer risk: a nested case-control study. Int J Cancer 82: 1-5, 1999

55. Holl K, Surcel HM, Koskela P, Dillner J, Hallmans G, Wadell G, Kaasila M, Olafsdottir GH, Ogmundsdottir HM, Pukkala E, Stattino P and Lehtinen M: Maternal Epstein-Barr virus and cytomegalovirus infections and risk of testicular cancer in the offspring: a nested case-control study. APMIS 116: 816-822, 2008.

56. Santos NBM, Villanova FE, Andrade PM, Ribalta J, Focchi J, Otsuka AY and Silva ID: Epstein-Barr virus detection in invasive and pre-invasive lesion of the uterine cervix. Oncol Rep 21: 403-405, 2009

57. Kim NR, Lin Z, Kim KR, Cho HY and Kim I: Epstein-Barr virus and $\mathrm{p} 16^{\mathrm{INK} 4 \mathrm{~A}}$ methylation in squamous cell carcinoma and precancerous lesions of the cervix uteri. J Korean Med Sci 20 : 636-642, 2005

58. Szostek S, Zawilinska B, Kopec J and Kosz-Vnenchak M: Herpesviruses as possible cofactors in HPV-16-related oncogenesis. Acta Biochimica Pol 56: 337-342, 2009.

59. Kuze T, Nakamura N, Hashimoto $Y$, Abe $M$ and Wakasa $H$ Clinicopathological, immunological and genetic studies of $\mathrm{CD} 30^{+}$anaplastic large cell lymphoma of B-cell type; association with Epstein-Barr virus in Japanese population. J Pathol 180: 236-242, 1996
60. Tazzari PL, de Totero D, Bolognesi A, Testoni N, Pileri S, Roncella S, Reato G, Stein H, Gobbi M and Stirpe F: An EpsteinBarr virus-infected lymphoblastoid cell line (D430B) that grows in SCID-mice with the morphologic features of a CD30 anaplastic large cell lymphoma, and is sensitive to anti-CD30 immunotoxins. Haematologica 84: 988-995, 1999.

61. Agarwal S, Ramanathan U and Naresh KN: Epstein-Barr virus association and ALK gene expression in anaplastic large-cell lymphoma. Hum Pathol 33: 146-152, 2002.

62. Noorali S, Pervez S, Yaqoob N, Moatter T, Nasir MI, Haroon S, Hodges E and Smith JL: Prevalence and characterization of anaplastic large cell lymphoma and its association with Epstein-Barr virus in Pakistani patients. Pathol Res Pract 200: 669-679, 2004.

63. Kim YC, Yang WI, Lee MG, Kim SN, Cho KH, Lee SL, Lee MW and Koh JK: Epstein-Barr virus on CD30 anaplastic large cell lymphoma involving the skin and lymphomatoid papulosis in South Korea. Int J Dermatol 45: 1312-1316, 2006.

64. Sasikala PS, Nirmala K, Sundersingh S, Mahli U and Rajkumar T: Frequency and distribution of Epstein-Barr virus infection and its association with $\mathrm{p} 53$ expression in a series of primary nodal non-Hodgkin lymphoma patients from South India. Int J Lab Hematol 32: 56-64, 2010

65. Ma L, Katz Y, Sharan KP, Scwarting R and Kim AS: Epstein-Barr virus positive anaplastic large cell lymphoma: myth or reality? Int J Clin Exp Pathol 4: 100-110, 2011.

66. Herling M, Rassidakis GZ, Jones D, Schmitt-Graeff A, Sarris AH and Medeiros LJ: Absence of Epstein-Barr virus in anaplastic large cell lymphoma: a study of 64 cases classified according to World Health Organization criteria. Hum Pathol 35: 455-459, 2004.

67. Kasai K, Kon S, Kikuchi K, Sato Y and Kameya T: Expression of carbohydrate antigens, p80NPM/ALK, cytotoxic cell-associated antigens, and Epstein-Barr virus gene products in anaplastic large cell lymphomas. Pathol Int 48: 171-178, 1998.

68. Lopategui JR, Gaffey MJ, Chan JK, Fierson HF, Sun LH, Bellafiore FJ, Chang KL and Weiss LM: Infrequent association of Epstein-Barr virus with CD30-positive anaplastic large cell lymphomas from American and Asian patients. Am J Surg Pathol 19: 42-49, 1995.

69. Hellier I, Dereure O, Segondy M, Guillot B, Baldet P and Guilhou JJ: Unlikely role of Epstein-Barr virus in the pathogenesis of primary cutaneous $\mathrm{CD} 30^{+}$anaplastic large cell lymphoma. Eur J Dermatol 11: 203-208, 2001.

70. Park CK and Ko YH: Detection of EBER nuclear RNA in T-cell lymphoma involving the skin - an in situ hybridization study. $\mathrm{Br}$ J Dermatol 134: 488-493, 1996.

71. Erkek E, Sahin S, Atakan N, Kokagoz T, Olut A and Goköz A: Examination of mycosis fungoides for the presence of Epstein-Barr virus and human herpesvirus- 6 by polymerase chain reaction. J Eur Acad Dermatol Venereol 15: 422-426, 2001.

72. Novelli M, Merlino C, Ponti R, Bergallo M, Quaglino P, Cambien I, Comessatti A, Sidoti F, Costa C, Corino D, Cavallo R, Ponzi AN, Fierro MT and Bernengo MG: Epstein-Barr virus in cutaneous T-cell lymphomas: evaluation of the viral presence and significance in skin and peripheral blood. J Invest Dermatol 129: 1556-1561, 2009.

73. Copur MS, Deshpande A, Mleczko K, Norvell M, Hernicek GJ, Woodward S, Frankforter S, Mandolfo N, Fu K and Chan WC: Full clinical recovery after topical treatment of Epstein-Barr virus associated cutaneous B-cell lymphoma in patient with mycosis fungoides. Croat Med J 46: 458-462, 2005.

74. Jeziorski E, Senechal B, Molina TJ, Devez F, Leruez-Ville M, Morand P, Glorion C, Mansuy L, Gaudelus J, Debre M, Jaubert F, Seigneurin J-M, Thomas C, Joab I, Donadieu J and Geissmann F: Herpesvirus infection in patients with Langerhans cell histiocytosis: a case-controlled sero-epidemiological study, and in situ analysis. PLos One 3: e3262, 2008

75. Csire M, Mikala G, Jako J, Masszi T, Janosi J, Dolgos J, Fule J, Tordai A, Berencsi G and Valyi-Nagy I: Persistent long-term human herpesvirus 6 (HHV-6) infection in a patient with Langerhans cell histiocytosis. Pathol Oncol Res 13: 157-160, 2007.

76. Sakata N, Toguchi N, Kimura M, Nakayama M, Kawa K and Takemura T: Development of Langerhans cell histiocytosis associated with chronic active Epstein-Barr virus infection. Pediatr Blood Cancer 50: 924-927, 2008.

77. Feng WH, Bruce I, Raab-Traub N, Busson P and Kenney SC: Chemotherapy induces lytic EBV replication and confers ganciclovir susceptibility to EBV-positive epithelial cell tumors. Cancer Res 62: 1920-1926, 2002 . 
78. Huang J, Chen H, Hutt-Fletcher L, Ambinder F and Hayward SD: Lytic viral replication as a contributor to the detection of Epstein-Barr virus in breast cancer. J Virol 77: 13267-13274, 2003.

79. Lee $\mathrm{CH}$, Yeh TH, Lai HC, Wu SY, Su IJ, Takada K and Chang Y: Epstein-Barr virus Zta-induced immunomodulators from nasopharyngeal carcinoma cells upregulate interleukin-10 production from monocytes. J Virol 85: 7333-7342, 2011.

80. Murata T and Tsurumi T: Epigenetic modification of the Epstein-Barr virus BZLF1 promoter regulates viral reactivation from latency. Front Genet 4: 53, 2013.

81. Shimakage $M$, Miyata $Y$, Inoue $H$, Yutsudo $M$ and Hakura $A$ : Increased sensitivity of EBNA2-transformed rat fibroblasts to ionizing radiation. Int J Cancer 68: 612-615, 1996.

82. Wang ZY, Liu QF, Wang H, Jin J, Wang WH, Wang SL, Song YW, Liu YP, Fang H, Ren H, Wu RY, Chen B, Zhang XM, Lu NN, Zhou LQ and Li YX: Clinical implications of plasma Epstein-Barr virus DNA in early-stage extranodal nasal-type NK/T-cell lymphoma patients receiving primary radiotherapy. Blood 10: 2003-2010, 2012.

83. Thomas TO, Agrawal P, Guitart J, Rosen ST, Rademaker AW, Querfeld C, Heyes JP, Kuzal TM and Mittal BB: Outcome of patients treated with a single-fraction dose of palliative radiation for cutaneous T-cell lymphoma. Int J Radiat Oncol Biol Phys 85: 747-753, 2013.

84. Shimakage M, Kimura M, Yanoma S, Ibe M, Yokota S, Tsujino G, Kozuka T, Dezawa T, Tamura S, Ohshima A, Yutsudo M and Hakura A: Expression of latent and replicative-infection genes of Epstein-Barr virus in macrophages. Arch Virol 144: 157-166, 1999.

85. Masy E, Adriaenssens E, Montepellier C, Crepieux P, Mougel A, Quatannens B, Goormachtigh G, Faumont N, Meggetto F, Auriault C, Groux H and Coll J: Human monocytic cell lines transformed in vitro by Epstein-Barr virus type II latency and LMP-1-dependent proliferation. J Virol 76: 6460-6472, 2002.

86. Salek-Ardakani S, Lyons SA and Arrand JR: Epstein-Barr virus promotes human monocyte survival and mutation through a paracrine induction of IFN-alpha. J Immunol 173: 321-331, 2004

87. Tugizov S, Herrara R, Veluppillai P, Greenspan D and Palefsky JM: Epstein-Barr virus (EBV)-infected monocytes facilitate dissemination of EBV within the oral mucosal epithelium. J Virol 81: 5484-5496, 2007.

88. Li H, Ikuta K, Sixbey JW and Tibbetts SA: A replicationdefective gammaherpesvirus efficiency establishes long-term latency in macrophages but not in B cells in vivo. J Virol 82: 8500-8508, 2008

89. Hwang KK, Chen X, Kozink DM, Gustilo M, Marshall DJ, Whitesides JF, Liao XH, Catera R, Chu CC, Yan XJ, Luftig MA, Haynes GF and Chiorazzi N: Enhanced outgrowth of EBV-transformed chronic lymphocytic leukemia B cells mediated by coculture with macrophage feeder cells. Blood 119: e35-e44, 2012

90. Andereesen R, Grugger W, Lohr GW and Bross KJ: Human macrophages can express the Hodgkin's cell-associated antigen Ki-1 (CD30). Am J Pathol 134: 187-192, 1989.

91. Balkwill $\mathrm{F}$ and Mantovani A: Inflammation and cancer: back to Virchow? Lancet 357: 539-545, 2001.

92. Qian BZ and Pollard JW: Macrophage diversity enhances tumor progression and metastasis. Cell 141: 39-50, 2010.

93. Biswas SK and Mantovani A: Macrophage plasticity and interaction with lymphocyte subsets: cancer as a paradigm. Nat Immunol 11: 889-896, 2010.

94. Mantovani A: B cells and macrophages in cancer: yin and yang. Nat Med 17: 285-286, 2011.

95. Hamada I, Kato M, Yamasaki T, Iwabuchi K, Watanabe T, Yamada T, Itoyama S, Ito $\mathrm{H}$ and Okada $\mathrm{K}$ : Clinical effects of tumor-associated macrophages and dendritic cells on renal cell carcinoma. Anticancer Res 22: 4281-4284, 2002.

96. Komohara Y, Hasita H, Ohnishi K, Fujiwara Y, Suzu S, Eto M and Takeya M: Macrophage infiltration and its prognostic relevance in clear cell renal cell carcinoma. Cancer Sci 102: 1424-1431, 2011.
97. Liou P, Bader L, Wang A, Yamashiro D and Kandel J: Correlation of tumor-associated macrophages and clinicopathological factors in Wilms tumor. Vasc Cell 5: 5, 2013.

98. Shimakage M and Sakamoto H: Macrophage involvement in Epstein-Barr virus-related tumors. Exp Ther Med 1: 285-291, 2010.

99. Thorley-Lawson DA: EBV the prototypical human tumor virus - just how bad is it? J Allergy Clin Immunol 116: 251-261, 2005.

100. Vieira P, de Waal-Malefyt R, Dang MN, Johnson KE, Kastelein R, Fiorentino DF, DeVries JE, Roncarolo MG, Mosmann TR and Moore KW: Isolation and expression of human cytokine synthesis inhibitory factor cDNA clones: homology to Epstein-Barr virus open reading frame BCRF1. Proc Natl Acad Sci USA 88: 1172-1176, 1991.

101. Miyazakai I, Cheung RK and Dosch H-M: Viral interleukin 10 is critical for the induction of $\mathrm{B}$ cell growth transformation by Epstein- Barr virus. J Exp Med 178: 439-447, 1993.

102. Hsu DH, de Waal Malefyt R, Fierentino DF, Dang MN, Vieira P, DeVries V, Spits H, Mosmann TR and Moore KW: Expression of interkeukin-10 activity by Epstein-Barr virus protein BCRF1. Science 250: 830-832, 1990.

103. Jochum S, Moosmann A, Lang S, Hammerschmidt W and Zeidler R: The EBV immunoevasins vIL-10 and BNLF2a protect newly infected $\mathrm{B}$ cells from immune recognition and elimination. PLoS Pathog 5: e1002704, 2012.

104.de Waal Malefyt R, Haanen J, Spits H, Roncarolo MG, te Velde A, Figdor C, Johnson K, Yssel H and de Vries JE: Interleukin 10 (IL-10) and viral IL-10 strongly reduce antigen-specific human $T$ cell proliferation by diminishing the antigen-presenting capacity of monocytes via downregulation of class II major histocompatibility complex expression. J Exp Med 174: 915-924, 1991.

105. Sica A, Allavena P and Mantovani A: Cancer related inflammation: The macrophage connection. Cancer Lett 264: 204-215, 2008.

106. Suzuki T, Tahara H, Narula S, Moore KW, Robbins P and Lotze MT: Viral interleukin 10 (IL-10), the human herpesvirus 4 cellular IL-10 homologue, induces local anergy to allogeneic and syngeneic tumors. J Exp Med 182: 477-486, 1995.

107.Kanai K, Satoh Y, Yamanaka H, Kawaguchi A, Horie K, Hoshikawa Y, Sata T and Sairenji T: The vIL-10 gene of the Epstein-Barr virus (EBV) is conserved in a stable manner except for a few point mutations in various EBV isolates. Virus Genes 35: 563-569, 2007.

108. Chao Y, Jing Y, Jia Y, Wang Y, Zhao C and Luo B: Conservation and mutation of viral interleukin-10 gene in gastric carcinomas and nasopharyngeal carcinomas. J Med Virol 83: 644-650, 2011.

109. Lee JH, Lee GT, Woo SH, Ha YS, Kwon SJ, Kim WJ and Kim IY: BMP-6 in renal cell carcinoma promotes tumor proliferation through IL-10-dependent M2 polarization of tumor-associated macrophages. Cancer Res 73: 3604-3614, 2013.

110. Ghosh SK, Perrine S and Faller DV: Advances in virus-directed therapeutics against Epstein-Barr virus-associated malignancies. Adv Virol: Mar 5, 2012 (Epub ahead of print). doi: 10.1155/2012/509296.

111. Feng WH, Israel B, Raab-Traub N, Busson P and Kenney SC: Chemotherapy induces lytic EBV replication and confers ganciclovir susceptibility to EBV-positive epithelial cell tumors. Cancer Res 62: 1920-1926, 2002.

112. Fu DX, Tanhehco Y, Chen J, Foss CA, Fox JJ, Chong JM, Hobbs RF, Fukayama M, Sgouros G, Kowalski J, Pomper MG and Ambinder RF: Bortezomib-induced enzyme-targeted radiation therapy in herpesvirus-associated tumors. Nat Med 14: $1118-1122,2008$. 